\title{
The Size of Underground Economy in Albania
}

\section{Brunela Trebicka, Phd candidate}

Universiteti "Aleksandër Moisiu" Durrës

\section{Doi:10.5901/ajis.2014.v3n4p503}

\section{Abstract}

The main purpose of this paper is to assess the size of the underground sector of the economy in Albania by using the Indirect Approach - Currency Demand Approach. A few studies have tried estimate the size of the informal economy in Albania in the previous years and there's no evidence of recent estimates of informality. Also, there are some other available studies which give some point assessments of informality in Albania but without information on its development over time. Using indirect measurement approaches we found that the size of the underground economy still accounts for a large share to GDP, but there is a decrease in size on the last years. This may be the result of vast reforms and a formalization process undertaken by the Albanian governments over time. Despite these results, it's important to highlight the fact that the average ratio of the underground economy to GDP presents a declining trend over the period $1998-2013$.

Keywords: Underground Economy, Indirect Approaches, Currency Demand Approach, Albania.

\section{Introduction}

\subsection{What is the underground economy?}

In economics, the term "underground" economy (sometimes referred to as the black economy, hidden economy, shadow economy, nonofficial economy or informal economy) refer to activities that occur in the economy but that are not officially reported. This sector can include such things as street vendors from local retailers for profits from production and in some cases family and industrial products. Businesses operating in informality are able to avoid taxes and regulations but suffer from capacity but suffer from the inability to effectively enforce contracts (as the business is operating illegally) and may waive formal credit markets. While it is clear that this phenomenon exists, a standard definition of the informal sector is not found in the literature. However, there are many definitions used in different studies.

We will use the definition of (Feige, 1990). He has considered the underground economy as the economy that does not "adhere to rules set", present in the official (formal) economy. This means that the underground economy can be defined only in the specific context of the institutional structure that surrounds it.

\subsection{Methods of measuring Underground economy}

The informal sector is still not very clear compared to other economic sectors. Part of the problem is that this sector is very difficult to measure. This is because the individuals operating in this sector hide their activities, and have stronger incentives to hide them, including fear of punishment by the state.

There are two main methods for measuring the underground economy: direct method and indirect method. Direct method is done via questioners and observation.

Indirect approach is done with the help of macroeconomic figures. One such method is the method which is based on the Monetary Approach to the request of the currency. In this method the researchers calculate the amount of money you have in a given economy and what is actually in use. Part "extra" money demand is assumed the used in the informal sector. This method requires that certain strong assumptions about the informal sector.

The main problem in this paper is to estimate the annual size of the informal economy in Albania for the period 2000-2012. 


\section{Literature Review}

(Gutmann, 1977) is the first economist who calculated the size of the "underground economy" using the method of cash in circulation. Guttman defines "underground" economy as "large amount of income not declared and undeclared work and employment". ${ }^{1}$ Participants in the underground economy, by Gutmann, potentially include anyone involved in cash transactions as Retail sales, personal services, illegal activities, restaurants, car washes, garages, bars, payments for part-time work, bribery etc.

He noted that the circulation of currency is rising faster than the demand for deposits in the United States in 1976, and argued that "the currency is the only form of money appropriate for transactions that are not recorded and are not taxed; inequality is a reflection in the growth of underground economy. He calculated the ratio of currency in circulation to demand deposits for the period 1937-1940 as a standard period, and assumed that the amount of demand for legal currency transactions in 1976 was the same percentage as the demand for deposits in 1937-1941.

Percentage of outstanding loans in 1976 was the sum of currency required for underground transactions. Taking the ratio of currency in circulation to the size of GNP, he estimated the size of underground economy in that year.

According to (Feige, 1989) the underground economy includes all unreported activities that are not measured by current techniques of "sociaty" and economic activity monitoring.

According to (Smith, 1994), underground economy is "market-based production of goods and services, legal and illegal, that escapes the official estimates of GDP". Thus, a definition of underground economy is very broad and can include both legal activities as undeclared income that would normally be reported in the GDP, and also includes illegal activities as well as smuggling, fraud, prostitution and money laundering.

(Tanzi, 1983) is considered one of the pioneers in the development of a method of "currency approach" in calculating the size of the informal economy and tax evasion. He assumed that the higher rate of income tax is the main cause of informal economic transactions. Tanzi's method is based on an econometric model assessment for demand for money in circulation in the economy which is used to calculate the effect of corporate tax rates in this application, and then, under specific assumptions, estimates the level of informal economy and tax evasion in the US during the years 1930-1980.

Tanzi included in his study three other explanatory variables: per capita income; ratio of total wages to national income; and interest rate (weighted) for deposits. Achieving a real income per capita results in decreasing the ratio of currency (the currency ratio). Report total payroll wages in personal income was assumed to be positively associated with the ratio of currency (the currency ratio) since wages are paid mostly in cash, and the interest rate on time deposits was used to measure the cost of keeping opportunistic cash.

He assumed that the ratio of currency in circulation to money supply $(\mathrm{C} / \mathrm{m} 2)$ is a function of the rate of income tax besides other explanatory variables.

Currency Approach method is applied by many OECD countries for the calculation of the underground economy. (Matthews, 1982) studied the effect of the rate of income tax and value added tax at the request of the currency report with the demand for savings accounts in the UK economy in England. Using this connection he estimates the informal economy in England as $7.5 \%$ of GDP.

(Klovland, 1984) also tested the effect of the marginal tax rate on the demand for currency in Norway and Sweden. While the estimates for Sweden confirmed the positive effect of marginal tax rates on the demand for currency, Klovland could not substantiate this for Norway. In Sweden he estimated the underground economy for 3 to 20 percent of GDP, depending on the different characteristics and depending on the definition used for the tax rate.

(Thomas, 1999) stressed that a number of "heroic assumptions" are needed to make appropriate calculations. Thomas also answered questions from the assumption that the movement of money as equal in both economies, both formal and informal, as unrealistic and unsubstantiated.

(Bajada, 1999) used currency approach method to calculate the underground economy in Australia. He said that when government control is strict, many individuals and businesses move their activities to the underground sector. The consequences are clear: policymakers have imperfect knowledge about the economic situation. Although there is considerable international literature about the size of the underground economy, academics and public officials seem to have paid much attention to economic behavior illegal in Australia. Through his study, Bajada calculated and illustrated underground economy and its existence has consequences for the nature of the business cycle in Australia.

${ }^{1}$ Gutmann, P. M. (1977). The Subterranean Economy. Financial Analysts Journal. Page 26 
(Giles, 1999) used the non-parametric regression analysis to investigate the link between effective tax rate and the relative size of the underground economy using data in New Zealand. Currency approach model was used to simulate the effects of hypothetical tax changes in the size of the underground economy in New Zealand and to draw conclusions for policymakers.

(Schneider \& Enste, 2002) used the currency approach method to calculate the underground economy in 22 countries in transition and 22 OECD countries. Using the currency demand and DYMIMIC approaches calculations are presented in relation to the size of the underground economy in 22 Transition and 21 OECD countries. Over the years 2001/2002 in 21 OECD countries underground size (in percent of official GDP) was estimated for $16.7 \%$ of "official" GDP and in 22 transition countries 38.0\%. The average size of the workforce in the underground economy (in percent of working-age population) in 1998-1999 in seven OECD countries was $15.3 \%$ and in 22 countries in transition, was $30.2 \%$. He concluded that increasing the fiscal burden and social security contributions combined with increased regulatory activity are the driving force for increasing the size of the underground economy.

(Bajada, 2005) modifies the Tanzi's model using error correction model (ECM error correction model) and including social assistance variable together with other variables to calculate the demand for money in circulation in Australia using data quarterly for the period 1967-1996. This period was divided into five business cycles. He sought to calculate "excess sensitivity" of this variable and variable tax rate in the underground economy during business cycles. He found that the average increase in tax rates and increased social assistance benefits in Australia prompted the Australian people engage in underground economic activities to supplement their disposable income. He came to the result that the underground economy in Australia increased from 13.9 percent of GDP in the first cycle of the business (in late 1960) to around 15 percent of GDP in mid-1996 in the fifth round business (1994-1996), and reaches a peak of 15.7 percent in 1974 in the second cycle of business (1974-1980). He concluded that "a significant underground economy and showed unstable have negative implications on the nature of business cycle in Australia, namely the existence of a non-negligible informal economy generated volatile business cycles"2

(Simanjuntak, 2008), discussing Bajada's work, analyzes some downsides to using the ECM method in the evaluation of the underground economy. He argued that the application of the method of "excess sensitivity" of Bajada's using the single step model error correction (ECM) is unreliable and leads to poor results since there is no co-integration as a prerequisite for ECM mode. Simanjuntak presented an alternative approach using model vector error correction (vector error correction model already). His preliminary results suggested that the size of the informal economy in Australia is much lower than the results of Bajada's model. However, Simanjuntak argues that inference may not be reliable because the evaluation coefficients are already involved with the formula "excess sensitivity". He concluded that there is a need to make significant revisions in the method of excess sensitivity and to develop a reliable new method in order to calculate the most reliable underground economy.

(Ahumada, Alvaredo, \& Canavese, 2008) constructed a formal framework for the collection show that the method of the currency approach is correct only when the income elasticity of demand for money is one. They presented several estimates from several other studies applying corrections and showed that "the assumption of equal velocities along with the income elasticity estimates lower (higher) than one, resulting in biased figures above (below) for the underground economy ". Ahumada and his colleagues reviewed the cash method under aggregation shown that if the model of demand for money for a short time used to calculate the underground economy and whether it includes a variable pattern remained dependent (lagged dependent variable) then you will need an initial period known in which there is zero underground economy and informal requests for money. They conclude that "the only way to avoid ad hoc assumptions about currency values previously recorded is limited to measuring the size of the underground economy to ones based on estimates of long-term demand for money".

(Adriana Ana, 2012) investigate the connection between the economy and unemployment in Romania using the currency approach. She used the time data for the period 2000-2010, and concluded that the size of the underground economy has been decreasing over the period of study, starting with the beginning of the period with 36.5 percent of real GDP, at 31.5 percent of GDP that real mid 2010. She concluded that the official unemployment has a negative effect and statistically significant effect on the level of the underground economy, while in the long term, the unemployment rate has a positive effect on the economy.

${ }^{2}$ Bajada, C. (2005). Unemployment and the underground economy in Australia. Page 380 


\section{The Size of Underground Economy}

Currency approach method, as mentioned above, is a method used to measure underground economy by many economists. This method assumes that the main reason that drives people to go into the informal economy is taxation. Also this method assumes that the underground economy make people use money for transactions instead to carry them through the bank, so there is not a trace of these transactions in order to avoid tax payments. Therefore Currency Approach Method uses the model of demand for money in circulation to calculate the extra demand for the currency.

Once we calculate this request "extra" for currency, we calculate the size of the informal economy by applying the speed of movement of money.

Here we will estimate the annual size of the informal economy in Albania using the method of the Monetary Approach to the period 1993-2013.

The first step is the calculation of the demand for money in circulation in Albania for the period mentioned. To calculate this, we use the following equation:

$M Q P F t=\beta 0+\beta 1 T V S H t+\beta 2 T A t+\beta 3 T D t+\beta 4 G N P P t+\beta 5 N I t+\beta 6 B A N K t+\beta 7 D U M t+\mu$

This equation represents the demand for currency in qarkullin in Albania.

Where:

$M Q P F_{t}$ variable is the currency in circulation per capita

TVSH variable is is effective tax from from sales (proportion of VAT revenue to GDP)

TA variable is the effective rate of income (ratio of income from other taxes to GDP)

TD is effective customs duty tax (ratio of custom revenues to total revenues from imports)

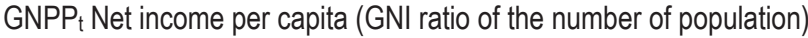

$\mathrm{Nlt}$ is the average interest rate for savings deposits

BANK $t$ is the amount of cash outside banks (ratio of the number of banks with number of population)

DUM is the dummy variable that indicates Depreciation of albanian lek agains other currencies.

Since Monetary Approach method assumes the primary cause of the informal economy is high taxation in the economy, the calculation of the demand for currency in Albania will be used to determine the demand for currency "extras" that results as a consequence of taxation in Bangladesh for the period of study .

After checking the data with ADF test, we see that data is not stationary. So the first step is the conversion of the first differential of variables in order to overcome the problem of unit root.

The above equation is calculated by the method OLS (Ordinary Least Square) through the program E-views.

The result shows that the model is generally important (Significant) the probability of F-Statistic equal to $0.8 \%$ (less than $5 \%$ ).

Signs of coefficients of all the variables of the model are as expected, in line with economic theory.

TD's coefficient is negative and highly significant at $5 \%$. This confirms the assumption of reduction of customs duty (import tax), giving rise to the demand for money in circulation. So lowering the protection of domestic production (through the reduction of customs duty), will lead to growth of the informal economy.

And VAT coefficients have positive signs and are significant at $10 \%$. This confirms the assumption that high taxation on high income and sales taxation (value added tax, VAT) increases the demand for money in circulation to be used in the informal economy.

GNPP coefficient has positive sign whereas NI coefficient has negative sign, and both of these quotients are significant at 1 percent. This result is consistent with the theory that the increase in income has a positive effect on the demand for money and the interest rate increase has a negative effect on the demand for currency in circulation.

Since the variables in the model are all differentiated on the same scale (are differencial at first level), according to (Dell'Anno, 2007) ${ }^{3}$, the dependent variable MQPF can be calculated by multiplying the differential coefficients with variables level data.

Based on the Monetary Approach method, this gives us the total demand for money in circulation in Albania, which includes money demand as economies in both formal and informal. Since the demand for money prior to formal requests for informal, use the same equation with the assumption that income tax and VAT are zero and import taxes are fixed (maximum percentage take the years of this tax). From this we calculate the annual formal currency in circulation .

We assumed in the Currency Approach method that the speed of movement of money in the undergorund 
economy is the same as the speed of movement of money into the formal economy.

VFT $=$ year $=\mathrm{GDP} /$ Currency in circulation

Where year is the speed of movement of money in the informal economy,

VFT is the speed of the movement of money into the formal economy.

This speeds the movement of money is multiplied by annual demand value for money in the underground economy, estimationg in this way the undergorund economy in absolute value. To find the size of undergound economy as percentage of GDP, we divide this with GDP.

The following table represents the annual value of underground economy in Albania for the period 1993-2003.

\begin{tabular}{|c|c|}
\hline Year & Underground Economy (as \% to GDP) \\
\hline 1993 & $40.16 \%$ \\
\hline 1994 & $41.53 \%$ \\
\hline 1995 & $38.40 \%$ \\
\hline 1996 & $38.79 \%$ \\
\hline 1997 & $35.40 \%$ \\
\hline 1998 & $36.06 \%$ \\
\hline 1999 & $35.05 \%$ \\
\hline 2000 & $29.78 \%$ \\
\hline 2001 & $31.52 \%$ \\
\hline 2002 & $33.19 \%$ \\
\hline 2003 & $33.80 \%$ \\
\hline 2004 & $35.52 \%$ \\
\hline 2005 & $34.20 \%$ \\
\hline 2006 & $39.28 \%$ \\
\hline 2007 & $42.90 \%$ \\
\hline 2008 & $45.38 \%$ \\
\hline 2009 & $44.44 \%$ \\
\hline 2010 & $44.20 \%$ \\
\hline 2011 & $44.42 \%$ \\
\hline 2012 & $42.02 \%$ \\
\hline 2013 & $39.80 \%$ \\
\hline
\end{tabular}

Currency approach method calculates the average value of underground economy in Albania for the period 1993 - 2013 about 38.4 percent of GDP.

In absolute terms, the informal economy for this period averaged ALL 280.560 million. In 1993 measures the informal economy accounts for ALL 56,406.95 million and has grown every year. In 2013 it accounted for a value of ALL $557,330.54$ million. This increase is due to increased fiscal burden and changing form of taxation in Albania during the period.

Graphically informal economy in Albania for the period 1993 - 2013 is as follows.

The trend of the underground economy in Albania under the Currency Approach method shows that the underground economy moves between 30 percent of GDP and 45 percent of GDP.

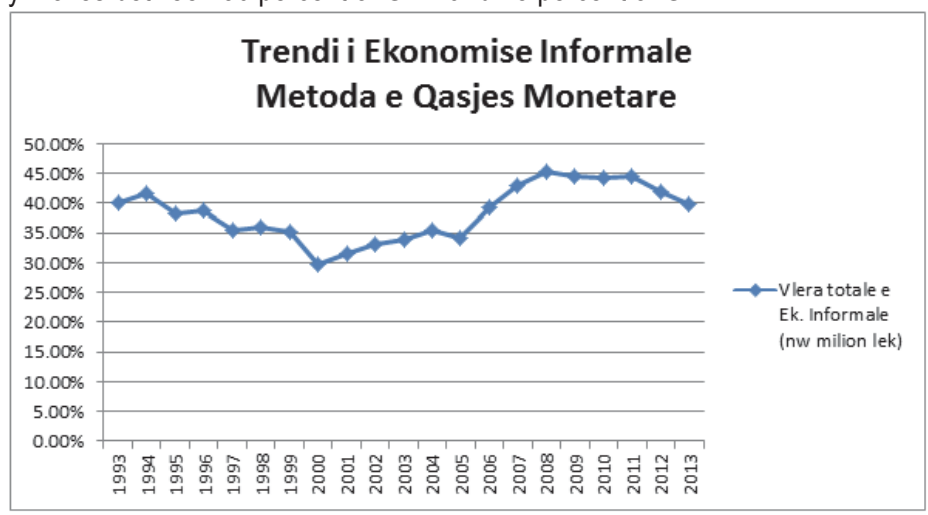




\section{Conclusions}

In this paper we calculate the underground economy in Albania for the period 1993-2013. The size of the underground economy was calculated as a percentage of GDP by the method of Currency Approach. It was found that the underground economy in Albania has a considerable size.

In this paper, as it was expected is found that tax is the main reason of underground economy. But, the custom duty tax has a negative effect on the size of the underground economy. When customs taxes rise, protection of domestic production increases, which makes the domestic manufacturer leave work in the underground economy and go to the official economy. Conversely, if customs duties decrease, protection of domestic production decrease, it makes manufacturers to move away from the official to the underground economy. Currency Approach method supported this hypothesis.

In this paper we also took into consideration the fact that most people keep their money out of the bank. This factor was used as a variable in the Currency Approach method. This variable had negative sign which supports the hypothesis that holding cash (outside the bank) has a negative effect on the size of the informal economy.

Results of the Currency Approach Method supports the theory that the income tax and sales taxes (value added tax) are the main causes of underground economy in Albania for the studied peiod.

\section{References}

Adriana Ana, M. A. (2012). The relationship between shadow economy and unemployment rate. A ARDL causality analysis for th e case of Romania. National Scientific Research Institute for Labour a Nd Social Protection, Bucharest Department of Statistics and Econometrics, Academy of Economic Studies, Buchares. Retrieved from http://www.crosportal.eu/sites/default/files/NTTS2013fullPaper_239.pdf

Ahumada, H., Alvaredo, F., \& Canavese, A. (2008). The monetary method to measure the shadow economy: The forgotten problem of the initial conditions. Economics Letters, 101, 97-99. doi:10.1016/j.econlet.2008.06.001

Bajada, C. (1999). Estimates of the underground economy in Australia. Economic Record, 75, 369-384. doi:10.1111/j.14754932.1999.tb02573.x

Bajada, C. (2005). Unemployment and the underground economy in Australia. Applied Economics. doi:10.1080/0003684042000291335

Dell'Anno, R. (2007). The shadow economy in Portugal: An analysis with the MIMIC approach. Journal of Applied Economics, X, 253277. Retrieved from http://econpapers.repec.org/RePEc:cem:jaecon:v:10:y:2007:n:2:p:253-277

Feige, E. L. (1989). The Underground Economies: Tax Evasion and Information Distortion. Retrieved May 03, 2014, from http://www.amazon.com/The-Underground-Economies-Information-Distortion/dp/0521262305

Feige, E. L. (1990). Defining and estimating underground and informal economies: The new institutional economics approach. World Development. doi:10.1016/0305-750X(90)90081-8

Giles, D. E. A. (1999). Measuring the Hidden Economy: Implications for Econometric Modelling. The Economic Journal, 109, F370F380.

Gutmann, P. M. (1977). The Subterranean Economy. Financial Analysts Journal. doi:10.2469/faj.v33.n6.26

Klovland, J. T. (1984). Tax evasion and the demand for currency in Norway and Sweden. Is there a hidden relationship? The Scandinavian Journal of Economics, 86, 423-439. doi:10.2307/3439653

Matthews, K. G. P. (1982). Demand for Currency and the Black Economy in the UK. Retrieved from http://www.emeraldinsight.com/doi/abs/10.1108/eb002537

Schneider, F. G., \& Enste, D. H. (2002). The Shadow Economy: Theoretical Approaches, Empirical Studies, and Political Implications. Retrieved September 22, 2014, from http://www.economics-ejournal.org/economics/journalarticles/2007-9/version_1

Simanjuntak, J. M. (2008). Currency Demand Modeling In Estimating The Underground Economy: A Critique on "Excess Sensitivity" Method and Support for VAR Framework.

Smith, P. (1994). Assessing the Size of the Underground Economy: the Canadian Statistical Perspectives. Canadian Economic Observer, Catalogue.

Tanzi, V. (1983). The Underground Economy in the United States: Annual Estimates, 1930-80 (L'Ã@conomie clandestine aux EtatsUnis: estimations annuelles, 1930-80) (La "economÃa subterrÃjnea" de Estados Unidos: Estimaciones anuales, 1930-80). IMF Staff Papers, 30(2), 283-305. Retrieved from http://ideas.repec.org/a/pal/imfstp/v30y1983i2p283-305.html

Thomas, J. (1999). Quantifying the black economy: "measurement without theory" yet again? The Economic Journal,, $381-389$. 